\title{
Banded Iron Formations (BIFs) and Associated Sediments Do Not Reflect the Physical and Chemical Properties of Early Precambrian Seas
}

\author{
Zeev Lewy \\ Geological Survey of Israel, Jerusalem, Israel \\ Email: lewy@gsi.gov.il
}

Received July 7, 2011; revised October 2, 2011; accepted November 15, 2011

\begin{abstract}
Ring-in-ring structures in Australian Early Precambrian banded iron formation (BIF) were identified as bubbling mud wavelets, which lithified during temporary exposure, contradicting the alleged BIF deep ocean origin. Least altered BIFs consist of alternating chert laminae with, and without iron oxides (or carbonates). They were precipitated during on-and-off periods of ferrous iron oxidation controlled by microbial oxygenic photosynthetic activity during solar illumination, which stopped during darkness as characterizing the Polar Regions, thus forming genuine annual varves. This polar environment is further corroborated by the magnetite-hematite-magnetite microcrystal layers in the iron-rich laminae reflecting mid-spring-summer-autumn changes in solar radiation, and by diamictite at the end of the sequence deposited from melting glaciers when the continental plate shifted to lower latitudes. BIF sequences in various countries comprise evaporates. They attest to intensive evaporation of the warm hydrothermal solution in restricted shallow lakes under the freezing dry climate up to silica (geyserite) precipitation referred to chert. The existence of oceans, midocean-ridges and island arcs during the Early Precambrian results from the misinterpreted oceanic origin of BIFs and the Phanerozoic occurrences of the associated mafic-ultramafic basalt flows (Greenstone Belt).
\end{abstract}

Keywords: Early Precambrian; BIF; Non-Marine; Polar Regions; Physical and Chemical Control

\section{Introduction}

Early Precambrian (Archean-Paleoproterozoic) banded iron formations (BIFs) consist of chert (amorphous silica) layers interbedded with iron minerals containing chert visually expressed by colour changes. BIFs accumulated during a restricted period of Earth's history (about 3.8 $1.8 \mathrm{Ga})$ in large basins discovered in all the continents [1,2]. BIFs contain $25 \%-35 \%$ total iron $\left(\mathrm{FeO}+\mathrm{Fe}_{2} \mathrm{O}_{3}\right.$, or $\mathrm{Fe}$ carbonates [3] for which they became the main source of world's iron. These ancient deposits underwent alteration to various degrees which improved the iron content of some of them [4]. Their high economic value promoted intensive chemical and sedimentological research of the least altered sequences to reconstruct their origin. The most intensively studied BIFs are the $2.475 \mathrm{Ga}$ old [5] Dales Gorge Member of the Brockman Iron Formation (Figure 1) in the Hamersley Basin, Western Australia [6, 7] and the Kuruman Iron Formation in Griqualand West Basin in South Africa (Figure 2) about 2.48 - 2.42 Ga old [8]. They are part of a succession of BIF units alternating with carbonate and volcanic rock deposited during periods of 150 - $200 \mathrm{Myr}$ (Figures 1, 2). Iron oxides are common in the Australian BIFs represented by the Dales
Gorge Member, whereas the South African BIFs like the Kuruman Iron Formation and are dominated by iron carbonates. Both formations preserve fine bedding of alternating iron-rich and iron-lacking chert laminae about 0.2 - $1.6 \mathrm{~mm}$ thick recalling annual varves [7,8]. These best preserved BIFs represent all other partly altered Lower Precambrian BIFs. They are interbedded with carbonates and shale layers comprising in places stromatolites and microbial microstructures $[9,10]$ reflecting aquatic, lowenergy settings. It was suggested [11] that dissolved iron upwelled from deep ocean sources, being later referred to vents along Mid-Ocean Ridges (MOR) [6]. The ferrous iron bearing sea-water or mud supposedly mixed periodically with shallow marine water rich in silica, whereas only silica precipitated during non-upwelling periods [6]. Ferrous iron oxidation was referred to photochemical oxidation by ultraviolet light [12], which the bivalent iron in the siderite-ankerite-dominated BIF of South Africa contradicts, or by anoxygenic phototrophic bacteria [13-15]. The third suggested process by oxygenic photosynthetic cyanobacteria $[16,17]$ is based on their fossil remains in BIFs and associated sediments [10]. The first two oxidation processes may have operated during Early Precam 

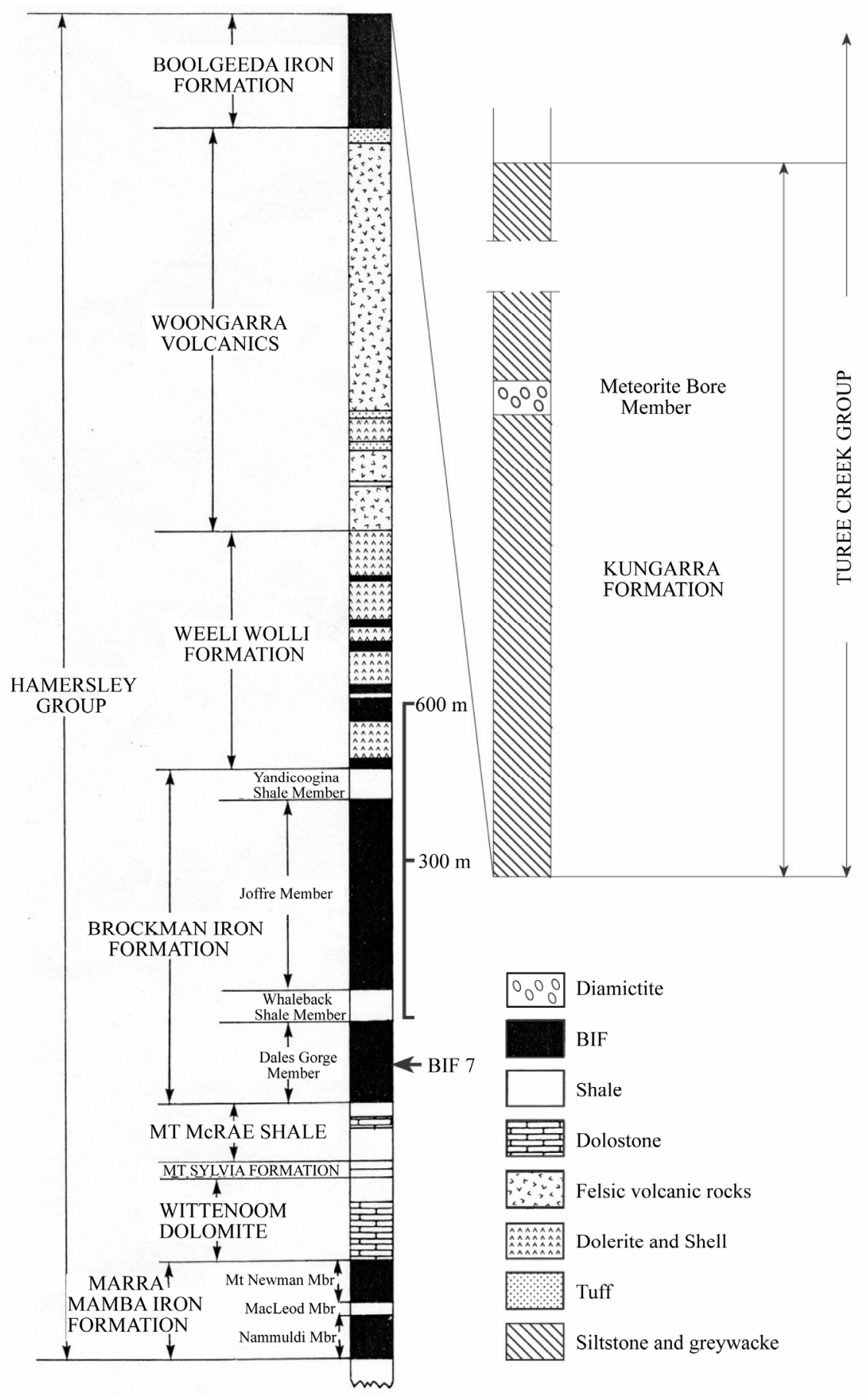

Figure 1. Stratigraphy of the Hamersley and Turee Creek groups in north Western Australia.

brian times. However, the highly significant role of oxygenic photosynthetic cyanobacteria in producing free oxygen, and hence ferrous iron oxidation, is evident by the change of the Early Precambrian anoxic world to oxygenated conditions on which most living organisms depend. The attempts to diminish the crucial contribution of oxygenic photosynthetic cyanobacteria to the origin of BIF and the development of life on Earth $[13,18]$ merely exaggerates the involvement of hypothetical processes.

Lack of terrestrial detritus in the putative marine finely bedded BIF suggested low-energy settings far from the coast. The occurrence of BIFs in huge basins in several countries was referred to deposition in the oceans $[19,20]$. Calcareous and clastic sediments with turbidite-like structures in between BIF layers advocated toward deposition in rather deep oceans $[21,22]$. In contrast to these sug- 


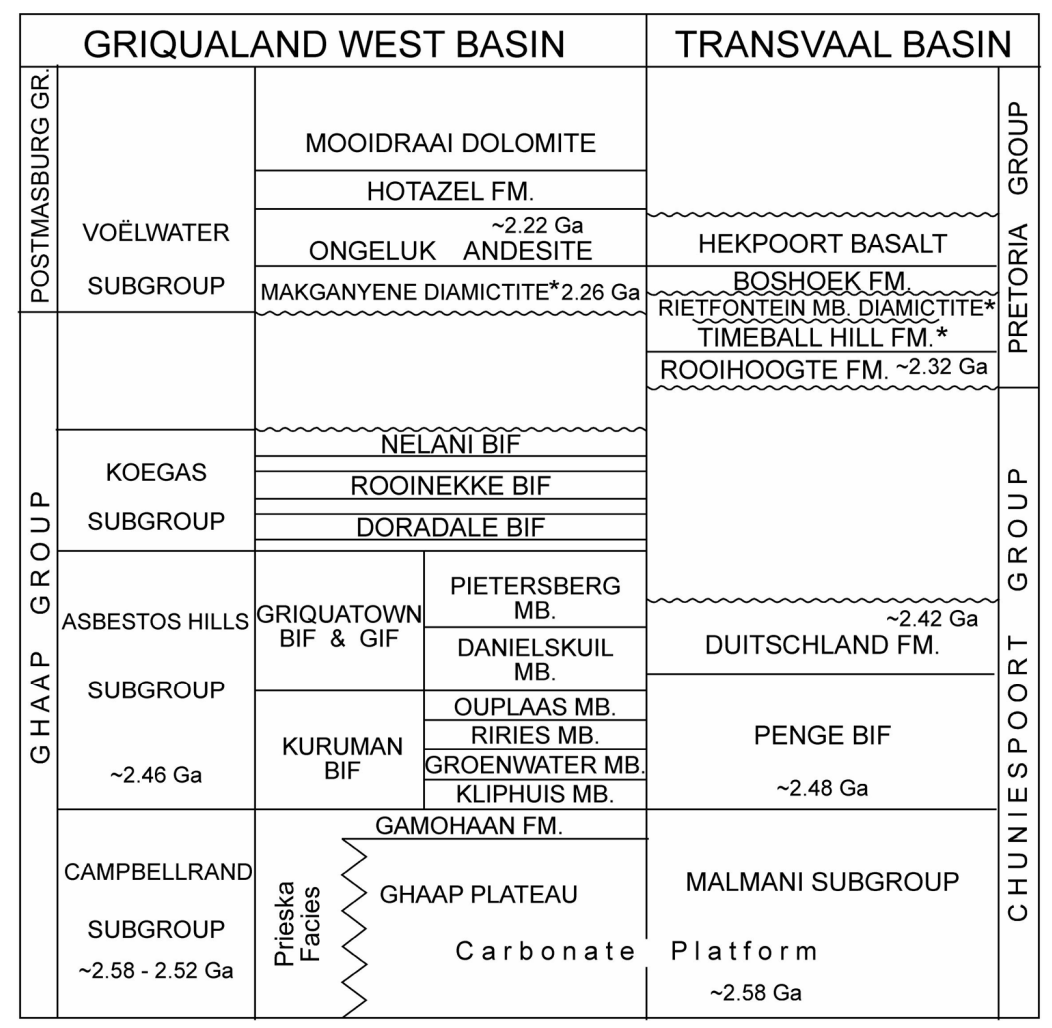

Figure 2. Stratigraphy of Lower Precambrian formations in South Africa.

gested open marine depositional setting other sedimentary reconstructions [7,23] interpreted the BIF depositional basin as a temporary lagoon in an arid climate (no runoff) undergoing intensive evaporation. This sedimentary reconstruction was abandoned by most BIF scholars who adopted the oceanic origin of this unique sediment, overlooking descriptions of evaporate minerals in various BIF successions such as in the Warrawoona Group in Western Australia [24] and in the Gamohaan Formation (Figure 1) below the Kuruman BIF in South Africa [25]. Accordingly, BIFs and associated sediments were intensively studied to reconstruct the chemical and physical properties of the Archean-Paleoproterozoic oceans and their changes with time. These alleged oceanic sediments indicated high temperatures of deposition (up to about $70^{\circ} \mathrm{C}$ ) $[26,27]$, which apart from hot hydrothermal sources were explained by meteorite impacts into the oceans [28]. The Campbellrand-Malmani carbonate platform (2560 - 2520 Ma) underlying BIFs in South Africa (Figure 2) contains abundant deposits of fibrous calcitic pseudomorphs after aragonite. They were explained as encrustations over the sea-floor precipitated from water supersaturated with respect to aragonite [29]. These physical and chemical properties attributed to Early Precambrian open marine water are puzzling, raising doubts on the oceanic origin of BIFs and associated sediments. Lately these doubts were substantiated by the incidental discovery of rare sedimentary structures [30] in the Dales Gorge Member BIF (Figure 1) attesting to very shallow aquatic depositional setting up to temporary exposure of the bottom sediment. The following re-evaluation of the vast literature on BIF properties and possible origin concluded a non-marine environment of deposition restricted to the Polar Regions [31], contradicting all previous theories and speculations. The present study elaborates on the chemical and sedimentological aspects of BIFs and associated carbonate lithologies to substantiate these concluded depositional settings of Early Precambrian BIFs.

\section{Bathymetric Significance of Dales Gorge Member Sedimentary Structures}

The suggested hydrothermal source of much of the iron and silica in BIFs [11] was generally accepted with a possible contribution from continental weathering [32]. Apart from large oceanic hydrothermal vents, which their role in BIF precipitation remained hypothetical, volcanolike cones were found on some layers of the Dales Gorge Member BIF attesting to fumaroles beneath the bottom [33]. Water flow kept open the crater and carried away in suspension the ejected sediment. A layer with ring-inring structures was recently discovered in the middle of the member [30,31]. These consist of several rings about $0.6-1.0 \mathrm{~cm}$ wide with a slightly arched surface, a shallow slit between adjacent rings, and a central plate $2-3$ 
$\mathrm{cm}$ in diameter (Figure 3). The ring-in-ring sets collide with, or overlap each other, truncating external rings. In non-truncated broad sets the structure flattens laterally and the slits fade and disappear. These lithified structures are identical to those being presently formed by bubbling mud in hydrothermal pools in Rotorua, New Zealand (Figure 4) through pulses of rising hot water with sediment, which create circular muddy wavelets expanding radially. These continuously changing planar circular structures form on the exposed sediment surface only. Otherwise the erupting mud would be suspended in the overlying water column leaving on the bottom volcano-like structures [33]. Clusters of similar volcanoes were found in the member (by H. Dalstra) surrounded by ring-inring structures (Figure 5) exhibiting fumarole activity during water-level rise from near zero when the surrounding rings were formed. All these sedimentary structures attest to hydrothermal water supplied from numerous fumaroles [7], which must have temporarily ceased for the stabilization of the ring-in-ring structures over the surface before being flooded. The rare chance of fossilization attributes these incidentally detected structures an extreme significance as bathymetric indicators of BIF depositional settings. The overall well-bedded BIF sediments found throughout the world attest to a low-energy continuous seepage of the hydrothermal water into the basin with occasional more intensive flow which created the sedimentary structures.

\section{Paleogeographic Significance of the Varve Structure in BIFs}

The least altered Dales Gorge Member (Western Australia) and the Kuruman BIF (South Africa) are well-bedded over their 500 - 600 kilometres long basins characterised by the recurring alternation of iron-rich and iron-lacking chert (amorphous silica) laminae recalling annual varves [7]. The pattern of a set of varves can be traced over more than 80 kilometres of the Hamersley basin [7,34]. This remarkably uniform extensive deposition on millimetre and submillimetre scale over at least $60,000 \mathrm{~km}^{2}$ of the Hamersley Basin cannot result from rising ferrousiron-bearing deep ocean water, mixing with photosynthetic oxygen-bearing shallow water [6], or from over-turn of these two water bodies in a stratified ocean. The extensive varve structure evidences that ferrous iron oxidation and precipitation started and stopped simultaneously over the thousands square kilometres wide basin during the continuous precipitation of amorphous silica (geyserite). Oxygen released by photosynthetic cyanobacteria forming mats over the whole bottom of the basin, as attested by their fossil relics [10], is the most obvious oxidation agent, being controlled by solar radiation in-

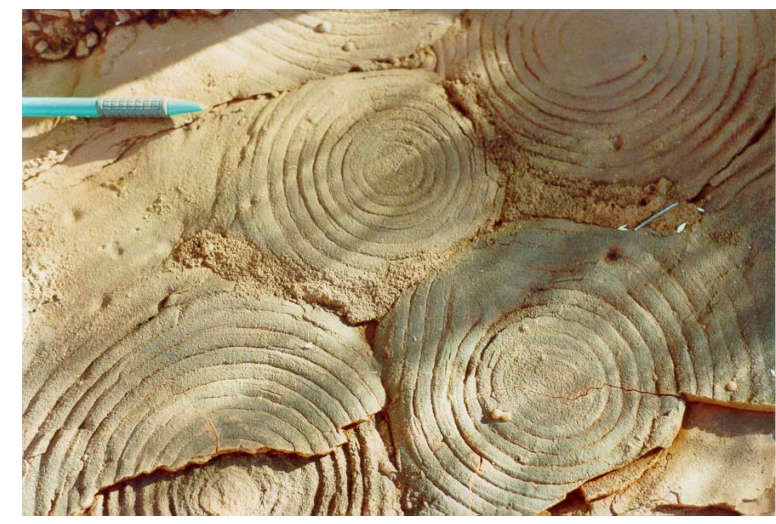

Figure 3. Ring-in-ring structures on a bedding surface in the Dales Gorge Member BIF, Hamersley Basin, Western Australia (photo by H. Dalstra).

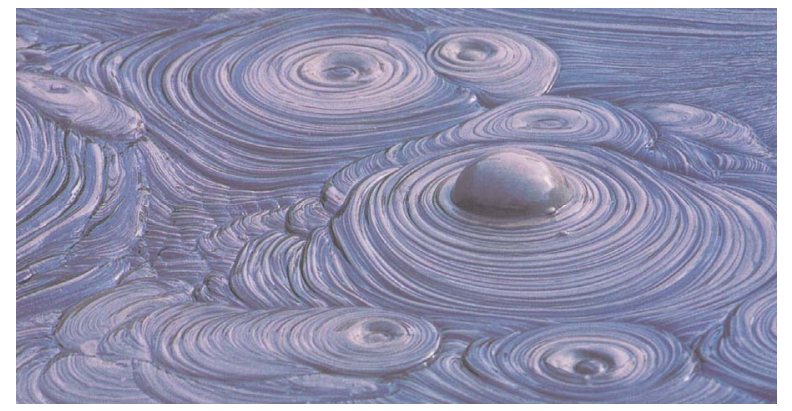

Figure 4. Bubbling mud circular wavelets at the surface of a mud pool in Rotorua, New Zealand (photo by B. Beresford).

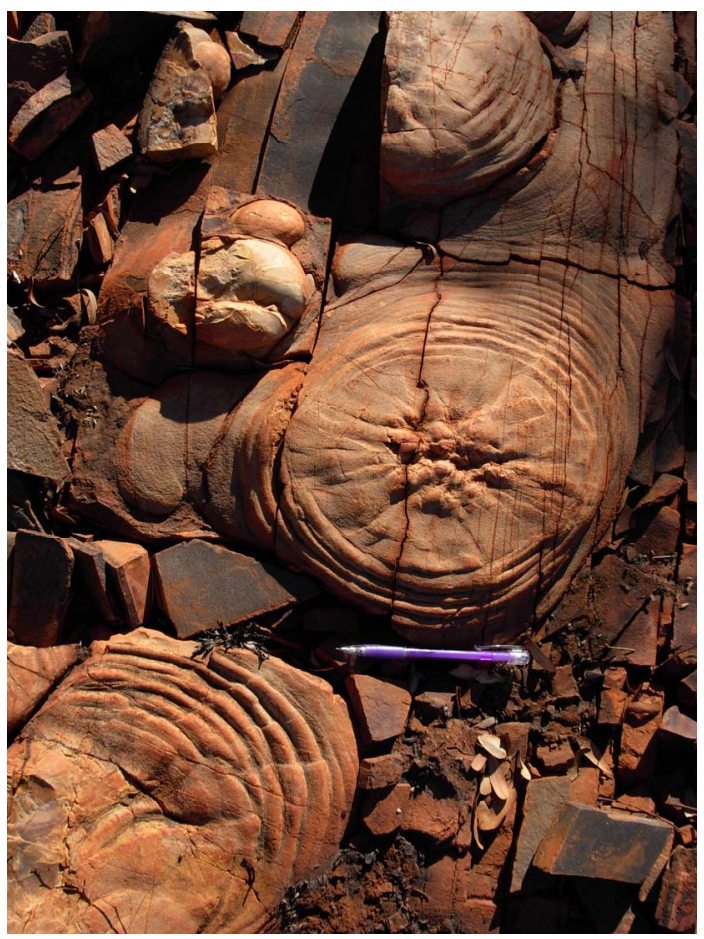

Figure 5. Volcano-like craters with basal ring-in-ring structures on bedding surface of Dales Gorge Member BIF (photo by H. Dalstra). 
tensity. Diurnal changes in solar illumination are too rapid to form the varves. Longer cyclic changes in solar illumination on Earth occur in the Polar Regions where illumination and darkness alternate every half year. There the solar radiation gradually changes its intensity toward maximum illumination during the polar summer and maximum darkness in winter. Remarkably well-preserved iron-rich chert lamellae consist of alternating fine layers of magnetite-haematite-magnetite microcrystals [6]. They were suggested to result from the over-growth of magnetite $\left(\mathrm{Fe}_{2} \mathrm{O}_{3} \mathrm{FeO}\right)$ on haematite $\left(\mathrm{Fe}_{2} \mathrm{O}_{3}\right)$ through the conversion of the latter [6]. However, the clear mineralogical differentiation between these related iron oxides recurring in repetitive iron-rich chert laminae attests to their original precipitation and not as the result of secondary diagenesis. The change of the iron ions from partly bivalent (magnetite) to all trivalent (hematite) and back undoubtedly reflect the increase and decrease in free oxygen content in the water (oxidation potential) from oxygenic photosynthesis activity. This activity is controlled by the annual change in solar radiation intensity rising from spring to a maximum in summer, and decreasing toward autumn. No other paleogeographic and climatic settings could have produced these delicate mineralogical features, thus providing striking evidence for the Polar Regions in addition to the characteristic varved structure.

Paleomagnetism analyses of Archean-Paleoproterozoic rocks in Australia, South Africa, North America and other parts of the world support high latitude positions of the BIF basins as part of the polar wander path of these continents [34-36]. The successions of BIF, carbonates and volcanic rocks in the Hamersley Basin, Griqualand West and Transvaal basins are topped by diamictite deposited from melting glaciers [37], probably when these plates shifted into lower latitudes and warmer climate [31]. These initial high-latitude paleo-positions of the diamictites at the top of BIF sequences were later emended to equatorial regions $\left(11^{\circ}+/-5^{\circ}\right)$ supporting a suggested synchronous global cooling and extensive glaciation [38, 39].

The freezing-cold and dry climate in the Polar Regions eliminated rain and terrestrial runoff that could supply terrigenous components into the BIF basin apart of airborne volcanic ash (altered into stilpnomelane). The up to about $70^{\circ} \mathrm{C}$ hot hydrothermal water [27] supplied into the huge lake was just below the highest temperature tolerated by extant cyanobacteria $\left(<70^{\circ} \mathrm{C}-73^{\circ} \mathrm{C}\right)$ [40] and by Precambrian ones as attested by their relics in BIF successions [10]. Part of the water infiltrated into subsurface and mixed with the rising hydrothermal water from deeper levels, keeping water circulation and mine- ral supply into the lake.

\section{Chemical Implications from the Composition of the Varves}

The iron-rich chert laminae in the varve structures of the Kuruman BIF (Figure 2) consist of ferrous iron $\left(\mathrm{Fe}^{2+}\right)$ carbonates (mainly siderite and ankerite) [8] as if oxidation by photosynthetic oxygen was not involved. Nevertheless, they were precipitated under the same controlling factor of solar radiation like the iron-oxides-bearing varves in the Australian BIFs. The released photosynthetic oxygen molecule $\left(\mathrm{O}_{2}\right)$ combined with dissolved gaseous $\mathrm{CO}$ supplied by the fumaroles into $\mathrm{CO}_{3}^{2-}$ which formed siderite with $\mathrm{Fe}^{2+}$. The occurrence of $\mathrm{CO}$ volcanic gas rather than $\mathrm{CO}_{2}$ is chemically more reasonable within the Early Precambrian anoxic hydrosphere. Accordingly both types of varves, whether consisting of iron-oxides-, or iron-carbonates-containing chert laminae were biochemically-precipitated as part of genuine annual varves controlled by solar illumination [31].

The delicate segregation between layers of magnetitehaematite-magnetite microcrystals in successive iron-rich chert laminae [6] attests to the original precipitation of each oxide under specific concentrations in the water of photosynthetic free oxygen prevailing over the whole huge basin. The direct precipitation of each of these oxides from the hydrothermal solution contradicts the assumed involvement of an intermediate phase of iron hydroxyoxides $[6,13,14,23,41]$. The postulated irradiation of UV photons on such intermediate phases for photochemical oxidation of $\mathrm{Fe}(\mathrm{II})$ is therefore rejected by the composition of the iron-rich chert laminae, as well as by the different mineralogical composition of BIFs in Australia (mainly oxides) and South Africa (mainly carbonates of ferrous iron). Actually, these attempts to look for ferrous iron oxidizing processes other than by oxygenic photosynthesis were not conclusive and left much doubts on their possible effectiveness [14]. Base on the alleged deep ocean environment of BIF deposition it was suggested [42] that dissolved silica in ocean surface water adsorbed onto the hydrous surface of iron hydroxides

$\left[\mathrm{Fe}(\mathrm{OH})_{3}\right]$, which precipitated and carried the silica to deepwater sediments along with the iron to form BIF. The well documented [6] direct precipitation in BIFs of each iron mineral without an intermediate phase, as well as the sedimentological structures attesting to shallow aquatic settings of BIF deposition [31] oppose this complicated scenario [42].

The sharp boundary between the iron-rich and ironlacking chert laminae indicates that the ferrous iron remained dissolved in the hydrothermal water when oxygenic photosynthesis ceased during dark periods and only amorphous silica precipitated. This is clear evidence for the total consumption of all free oxygen molecules re- 
leased into the water during solar illumination. No free oxygen molecules could have accumulated to form an oxygenated water layer that should have mixed with oceanic ferrous-iron-bearing solution for ferrous iron oxidation and precipitation as BIF.

The successions of the varves extending over the Hamersley Basin indicate that no meteoric water from snow fall or melting ice changed the chemistry of the lakewater during the polar summer when the iron-rich lamina on its alternating mineralogical composition precipitated. Perhaps ice melting did not occur, or was minor and confined to the lake margins. The lateral extension of the varves in which each lamina keeps its thickness over tens of kilometres of the Hamersley Basin enables lateral correlation of laminae sets of certain thickness pattern [7]. This remarkable lateral homogeneity [34] attests to the similar chemical and physical conditions changing simultaneously over the whole basin even through a minor increase or decrease in photosynthetic oxygen content as reflected by the magnetite-hematite-magnetite alternating layer in iron-rich chert laminae. This requires that the cyanobacteria extended over a level surface under the same water column through which the solar radiation penetrates. Cyanobacteria were not floating in the water column as plankton [28], but formed microbial mats and stromatolites on the bottom. The released oxygen immediately reacted with dissolved ferrous iron in the ambient water while the microbial organisms were protected from the damaging effect of free oxygen by the enveloping mucus.

\section{Depositional Setting of BIF-Associated Carbonates}

The theory on the rather deep oceanic depositional setting of BIF contradicted the shallow marine conditions attributed to the associated stromatolitic limestone occurring as alternating units, or lateral lithofacies changes. The Hamersley Group (Figure 1) contains dolostone units in between BIFs. Both BIF successions in Griqualand West and Transvaal Basin of South Africa (Figure 2) comprise limestone and dolostone referred to carbonate platform facies. In the Griqualand Basin shale and BIF beds increase in abundance southward to form the intermediate Prieska Facies, being followed by BIF dominated sediments. These relationships were interpreted as southward deepening of the basin [43] in contrast to evidence for shallowing [44]. These gradual and recurring lithofacies changes between BIF and carbonates "cannot be attributed to a change in environment of deposition" [8].

The precipitation of BIF from hydrothermal solutions flowing into the basin from numerous fumaroles scattered over the bottom $[7,8]$ provides the chemical control on these lithological changes between BIF and associated carbonates. Carbon and sulphur volcanic gases combined with photosynthetic oxygen in the hydrothermal water to form acids which prevented carbonate precipitation. Geyserite was deposited from the small water column of highly evaporated mineral-rich hydrothermal water, periodically mixing with iron minerals to form the BIF. Increase in water supply relative to rate of evaporation elevated the water level and diluted the mineral content and water acidity whereby BIF precipitation was replaced by carbonates. It is suggested that the iron- and manganese-rich carbonates of the Ghaap Plateau and the Malmani Subgroup (Figure 2) underlying the Kuruman and Penge BIFs precipitated like the iron-rich carbonates in these BIFs through the continuation of microbial oxygenic photosynthesis and the reaction of oxygen molecules with $\mathrm{CO}$ and associated $\mathrm{Ca}, \mathrm{Mn}, \mathrm{Mg}$ and other ions. Although the chemical process differs from the precipitation of Phanerozoic hot spring carbonates the term travertine (including friable dolomite crystals) is herein applied to most (or all) carbonate units in between BIF layers. The possible involvement of hydrothermal solutions in carbonate precipitation was mentioned in regard to their mineralization by iron and manganese by phreatic (fumaroles) water [43].

The Ghaap and Malmani carbonate complexes comprise stromatolite-like structures and rare microbial microstructures [8]. Filamentous microfossils occur in the Gamohaan Formation transition unit from the Ghaap Plateau to the Kuruman BIF [9]. These microbial structures and microfossils were regarded to evident the marine origin of the carbonate-BIF successions. Among them are up to $50 \mathrm{~m}$ long and $20 \mathrm{~m}$ wide low domes of laminated carbonate [45]. Some of the regular-sized stromatolitelike structures resemble those formed in hot spring pools in Yellowstone National Park, probably without any biological intervention [46]. The presence of microbial structures in these Precambrian carbonates suggests that some of the stromatolites are genuine. However, stromatolites occur in Eocene to present-day fresh water sediments $[47,48]$ and the exclusive marine habitat of the Early Precambrian stromatolites was not substantiated. All these clues support the conclusion that the carbonates and associated BIFs precipitated from the same hydrothermal water in the same basin despite the few seemingly-marine affinities. Accordingly, the fibrous aragonite encrustations in the Campbellrand-Malmani "carbonate platform" (Figure 2) do not attest to Neoarchean sea-water supersaturated with respect to aragonite [29], but to chemical settings in the shallow lake.

BIF (lutitic iron-formation) and arenitic (granular) ironformation are conformably overlain by shale-rich flyschlike sediments characterizing turbidites [20]. Turbiditelike structures in sandy (crystals) dolomite and shale in 
the Brockman Supersequence (Western Australia) were suggested to result from bottom currents or gravitydriven turbidity currents [21]. No turbidite-like features were described from the well-bedded BIFs. According to the reconstructed depositional settings of BIFs and associated carbonates and clastics the latter accumulated under a greater water column of several decimetres or a couple of meters. This water column enabled redeposition of the suspended carbonate crystals and fine clastics in graded bedding or turbidite-like structures after being agitated by periodical high-energy flow from the numerous fumaroles, or through occasional wind activity.

Granular iron-formation (GIF) is petrographically similar to BIF with which it is associated in the upper part of the Wittenoom Dolomite (Figure 1). Hence, these GIFs are derived from unconsolidated BIF by rip-up and agitation during water high-energy events [49]. The confusing occurrence of wave-agitated disrupted "deep marine" BIF sediment into GIF overlying laminated BIF was explained by strong storms reaching to rather deep seabottoms, or by turbidity currents. Layers of GIF and BIF composing the Griquatown Formation overlying the $\mathrm{Ku}$ ruman BIF in South Africa (Figure 2) suggest upwardshallowing storm dominated deposits [50]. This shallowing trend of the basin was also concluded on the basis of other sedimentological criteria [51]. The creation of GIF from the muddy BIF sediment within the shallow basin [31] can be related to periodical intensive fumarole activity disrupting sediment portions and disintegrating them by agitation in the water into small spherical and elliptical structures. These settled down in place, or after minor transport on top of their BIF source sediment.

\section{Erroneous Interpretation as Ocean-Water Paleotemperature Changes through Time}

Two studies reconstructed Precambrian paleotemperatures of sedimentary and microbial life environments carried out on samples from Australia, South Africa and North America. One study [27] was based on silicon isotopes and the other [26] compared analyzed extracted resurrected proteins to their extant relatives. These studies accepted the marine origin of the siliceous BIFs and the associated shale and carbonates which constituted their Archean-Paleoproterozoic samples. Despite different techniques both studies arrived to similar results suggesting the cooling of the ocean water from about $70^{\circ} \mathrm{C}$ $60^{\circ} \mathrm{C}$ in the Archean to $40^{\circ} \mathrm{C}-30^{\circ} \mathrm{C}$ in the upper Proterozoic. Their detailed data, however, clearly show two paleotemperature sets chronostratigraphically separated at about $1.8 \mathrm{Ga}$. The older samples originated from BIF sequences and yielded the high temperatures $\left(73^{\circ} \mathrm{C}\right.$ $57^{\circ} \mathrm{C}$ ) reasonable for hydrothermal water in restricted basins, whereas the post $1.6 \mathrm{Ga}$ marine sediments yielded about $40^{\circ} \mathrm{C}$ and less. The $1.5 \mathrm{Ga}$ long period (3.5 - 2.0 Ga) of assumed hot ocean-water [27] contradicts the suggested global glaciations at about $2.2-2.4$ Ga deduced from diamictites at the top of BIF sequences in Australia (Figure 1), South Africa (Figure 2) and North America [37,38]. Alternatively, these diamictites are suggested to have accumulated in freezing glaciers while the wandering plates were in the Polar Regions, being deposited during glacier melting when the plates shifted to lower latitudes [31].

\section{Doubts on the Existence of Archean-Paleoproterozoic Oceans}

The new reconstruction of BIF deposition in non-marine environments raises doubt on the assumption that oceans in their Phanerozoic configuration already existed in Archean-Paleoproterozoic times. Apart from turbidite-like structures in sediments in between BIF units [22] the associated mafic and ultramafic volcanic sequences and their metamorphosed Greenstone Belts were interpreted as originating from oceanic spreading centres (MOR) and island arcs according to Phanerozoic examples. "Their great lateral extent, with a recognisable internal stratigraphy, suggests that they were extruded over a very flat surface in a very mobile form [7]. Like the former basalt flows in the Hamersley Group [7] the bedded mafic and ultramafic volcanic sequences of the Archean Warrawoona Group (Western Australia) comprise in places pillow-lava flows with internal vesicular structure attesting to lava flow into aquatic environments of rather shallow depth. Associated evaporates indicate temporary extreme basin shallowing [52]. The Archean mafic and ultramafic basalt and volcaniclast sequence in the Pilbara Block (Western Australia) [53] is overlain by sediments with evaporites attesting to deposition in a closed to semi-closed marginal marine or lacustrine basin. Higher in this siliciclastic sequence evaporates are interbedded with BIF. Evidence for evaporites in Neoarchean deposits of South Africa and the Belingwe Greenstone Belt of Zimbabwe [54] corroborate the wide extent of the rather shallow to nearly level physiography of these extensive sedimentary basins. This low relief resulted in the wide distribution of the mafic and ultramafic volcanic lava flows and allochthonous siliciclasts and conglomerates, being locally associated with chert and evaporites $[55,56]$. The in places associated BIF units suggested deeper marine ("pelagic") environments of deposition [55] which were later totally rejected [31]. The thick successions reflect the rapid subsidence of the elongated basin nearly synchronous with sediment accumulation whereby these basins were temporarily covered by shallow water, or completely dry. Greenstone Belt mafic lavas commonly erupted through, or on a basement of continental crust 
suggesting their emplacement in a different tectonic setting than in Phanerozoic times [57]. The Onverwacht Group (3.4 Ga) in Transvaal, South Africa consists of volcaniclasts interbedded with carbonate both are in places silicified. "Deposition took place largely in shallow water, but no evidence was found to indicate whether the water was marine, fresh, or of some other composition. Turbidites are locally well developed but there is no compelling evidence for deposition in deep water except in northernmost areas" [57]. These sedimentary environments attest to a moderate topographical relief of Early Precambrian Earth without any evidence for oceans in their Phanerozoic configuration. The hitherto accepted hypothesis of the oceanic origin of BIFs did not agree with published evidence for BIFs with evaporates and shallow aquatic sediments whereby the origin of BIFs remained enigmatic [58] as in the latest two publiccations on the subject by a similar group of BIF scholars. One is a detailed review based on 380 references [59] which concludes that many aspects remain unsolved. The latest analysis [60] calls for further research of the factors controlling the temporal distribution of large iron formations, thus admitting that none of the numerous attempts to explain the origin of the Early Precambrian BIFs was convincing. The reconstructed non-marine environment of BIFs mode of precipitation in shallow lakes of warm hydrothermal water situated on continental plates while shifting through the Polar Regions [31] clarifies all the previously puzzling aspects in Early Precambrian BIF accumulation and is probably the correct explanation.

\section{Summary and Conclusions}

The hypothesis that the iron and silica comprising the Early Precambrian BIFs originated from Mid-OceanRidge-like features known from Phanerozoic deep oceans is contradicted by the discovery of ring-in-ring structures of bubbling mud wavelets preserved during exposure. BIF is associated with GIF, which is its high-energy detrital product through wave action. Evaporites in BIF successions hinted to their accumulation in restricted basins under intensive evaporation. These were huge, very shallow basins of hydrothermal water supplied by numerous fumaroles. Sedimentological and mineralogycal criteria restricted BIF precipitation to the Polar Regions attested to by the alternation of iron-rich and ironlacking chert (amorphous silica) laminae forming annual varves. These are controlled by half a year of solar illumination resulting in cyanobacteria oxygenic photosynthesis causing ferrous iron oxidation and precipitation, followed by half a year of darkness during which only silica (geyserite) continued to accumulate. The magnetite-hematite-magnetite composition of the iron-rich lamella corroborates the polar setting where solar radia- tion intensity rises and falls during spring-summer-autumn. Similar varve structure in South African BIFs composed of iron carbonates suggests that under the prevailing anoxic conditions $\mathrm{CO}$ rather than $\mathrm{CO}_{2}$ was involved in siderite precipitation $\left(\mathrm{CO}+\mathrm{O}_{2}+\mathrm{Fe}^{2+} \rightarrow\right.$ $\mathrm{FeCO}_{3}$ ), as well as in the deposition of carbonates as travertine. The magnetite-haematite-magnetite composed iron-rich chert laminae deposited in recurring varves over the wide basin evidence the direct precipitation of each oxide without any intermediate iron- hydroxide phase. The iron-lacking chert laminae attest to the immediate consumption of the biogenically released oxygen without accumulating in the water. Paleomagnetism points to high latitude positions of the wandering plates. Diamictite at the top of BIF successions in Australia, South Africa and North America were deposited from melting glaciers when the plates shifted to lower latitudes and do not attest to global glaciation. Carbon and sulphur volcanic gases formed acids with the photosynthetic oxygen in the highly evaporated hydrothermal water preventing the precipitation of carbonates. Thereby only geyserite accumulated throughout the year, which mixed with iron oxides and iron carbonates during solar illumination. Increased water supply and water-level rise lowered water acidity and changed BIF accumulation to the precipitation of lime-stone and dolostone enriched in iron and manganese in form of travertine deposited in the same basin. These fluctuations in water supply versus evaporation controlled the vertical and lateral lithofacies changes. The associated stromatolite-like structures are in part abiogenic as observed in similar structures in Phanerozoic travertine, but some may be genuine aquatic microbial structures and not exclusively marine. The high paleotemperatures yielded from BIFs and associated sediments are not applicable to the Precambrian oceans and reflect the temperature of the hydrothermal water of the lakes. The well-bedded structure of BIFs attests to a slow seepage of the hydrothermal water through the permeable BIF sediment. Occasionally higher-energy flow created bottom sedimentary structures, as well as agitated the muddy sediment and disintegrated it into sand-size particles forming GIF deposited close to its BIF source sediment. The concluded nonmarine origin of these BIFs opposes the attempts to apply the physical and chemical properties of BIFs and associated sediments to marine environments of that time. Archean-Paleoproterozoic sedimentary successions of mafic and ultramafic basalts (metamorphosed to greenstone) interbedded with volcaniclasts, siliciclasts, conglomerates, evaporates, carbonates and BIFs lack any evidence for deposition in oceanic basins, and raise doubt on the alleged existence of oceans in their Phanerozoic configuration at that time $[22,27]$. The non-marine mode of BIF accumulation clarifies the long-disputed origin of the economically most important 
iron ore and changes the paleogeographic and paleo-ecologic reconstructions of the Early Precambrian Earth.

\section{Acknowledgements}

Many thanks to Dr. Hilke Dalstra, Rio Tinto Exploration, Belmont, Australia, and to Bob Beresford manager of the New Zealand Cards Ltd. for permitting to use their photos, and to N. Almog, Geological Survey of Israel for the graphic work.

\section{REFERENCES}

[1] C. Klein, "Some Precambrian Banded Iron-Formations (Bifs) from around the World: Their Age, Geologic Setting, Mineralogy, Metamorphism, Geochemistry, and Origin," American Mineralogist, Vol. 90, No. 10, 2005, pp. 1473-1499. doi:10.2138/am.2005.1871

[2] A. F. Trendall, "The Significance of Iron-Formation in the Precambrian Stratigraphic Record," In: W. Altermann and P. L. Corcoran, Eds., Precambrian Sedimentary Environments: A Modern Approach to Ancient Depositional Systems, International Association of Sedimentologists Special Publication, John Wiley \& Sons, Inc., New York, 2002, pp. 33-66.

[3] M. Gole and C. Klein, "Banded Iron-Formations through Much of Precambrian Time," Journal of Geology, Vol. 89, No. 2, 1981, pp. 169-183. doi:10.1086/628578

[4] A. D. Webb, et al., "From Banded Iron-Formation to Iron Ore: Geochemical and Mineralogical Constraints from across the Hamersley Province, Western Australia," Chemical Geology, Vol. 197, No. 1-4, 2003, pp. 215-251. doi:10.1016/S0009-2541(02)00352-2

[5] A. L. Pickard, "SHRIMP U-Pb Zircon Ages of Tuffaceous mudrocks in the Brockman Iron Formation of Hamersley Range, Western Australia," Australian Journal of Earth Sciences, Vol. 49, No. 3, 2002, pp. 491-507. doi:10.1046/j.1440-0952.2002.00933.x

[6] R. C. Morris, "Genetic Modelling for Banded Iron-Formation of the Hamersley Group, Pilbara Craton, Western Australia," Precambrian Research, Vol. 60, 1993, pp. 243286. doi:10.1016/0301-9268(93)90051-3

[7] A. F. Trendall and J. G. Blockley, "The Iron-Formations of the Precambrian Hamersley Group, Western Australia, with Special Reference to the Associated Crocidolite," Western Australia Geological Survey Bulletin, Vol. 119, 1970, pp. 1-365.

[8] N. J. Beukes, "Paleoenvironmental Setting of Iron-Formations In The Depositional Basin of the Transvaal Supergroup, South Africa," In: A. F. Trendall and R. C. Morris, Eds., Iron-Formations: Facts and Problems. Development in Precambrian Geology, Vol. 6, 1983, pp. 131209. doi:10.1016/S0166-2635(08)70043-4

[9] C. Klein, et al., "Filamentous Microfossils in the Early Proterozoic Transvaal Supergroup: Their Morphology, Significance, and Paleoenvironmental Setting," Precambrian Research, Vol. 36, No. 1, 1987, pp. 81-94. doi:10.1016/0301-9268(87)90018-0
[10] J. W. Schopf, "Fossil Evidence of Archaean Life," Philosophical Transactions of the Royal Society, Vol. 361, No. 1470, 2006, pp. 869-885. doi:10.1098/rstb.2006.1834

[11] H. D. Holland, "The Oceans: A Possible Source of Iron in Iron-Formations," Economic Geology, Vol. 68, No. 7, pp. 1169-1172. doi:10.2113/gsecongeo.68.7.1169

[12] A. G. Cairns-Smith, "Precambrian Solution Photochemistry, Inverse Segregation, and Banded Iron-Formations," Nature, Vol. 276, No. 5690, 1978, pp. 807-808. doi: $10.1038 / 276807 \mathrm{a} 0$

[13] A. Kappler, et al., "Deposition of Banded Iron Formations by Anoxygenic Phototrophic Fe(II)-Oxidizing Bacteria," Geology, Vol. 33, No. 11, 2005, pp. 865-868. doi:10.1130/G21658.1

[14] K. O. Konhauser, et al., "Decoupling Photochemical Fe(II) Oxidation from Shallow-Water BIF Deposition," Earth and Planetary Science Letters, Vol. 258, No. 1-2, 2007, pp. 87-100. doi:10.1016/j.epsl.2007.03.026

[15] F. Widdel, et al., "Ferrous Iron Oxidation by Anoxygenic Phototrophic Bacteria," Nature, Vol. 362, No. 6423, 1993, pp. 834-836. doi: 10.1038/362834a0

[16] P. E. Jr. Cloud, "Significance of the Gunflint (Precambrian) Microflora," Science, Vol. 148, No. 3666, 1965, pp. 27-35.

[17] P. E. Jr. Cloud, "Paleobiological Significance of Ironformations," Economic Geology, Vol. 68, 1973, pp. 1135 1143. doi:10.2113/gsecongeo.68.7.1135

[18] K. O. Konhauser, et al., "Could Bacteria Have Formed the Precambrian Banded Iron Formations?" Geology, Vol. 30 , No. 12 , 2002, pp. 1079-1082. doi:10.1130/0091-7613(2002)030<1079:CBHFTP $>2.0$.C $\underline{\mathrm{O} ; 2}$

[19] C. J. Bjerrum and D. E. Canfield, "Ocean Productivity about 1.9 Gyr Ago Limited by Phosphorus Adsorption Onto Iron Oxides," Nature, Vol. 417, No. 6885, 2002, pp. 159-162. doi:10.1038/417159a

[20] B. M. Simonson, "Sedimentological Constraints on the Origin of Precambrian Iron-Formations," Geological Society of America Bulletin, Vol. 96, 1985, pp. 244-252. doi:10.1130/0016-7606(1985)96<244:SCOTOO >2.0.CO; $\underline{2}$

[21] B. Krapež, et al., "Hydrothermal and Resedimented Origins of the Precursor Sediments to Banded Iron Formation: Sedimentological Evidence from the Early Palaeoproterozoic Brockman Supersequence of Western Australia," Sedimentology, Vol. 50, No. 5, 2003, pp. 979-1011. doi:10.1046/j.1365-3091.2003.00594.x

[22] A. L. Pickard, et al., "Deep-Marine Depositional Setting of Banded Iron Formation: Sedimentological Evidence From Interbedded Clastic Sedimentary Rocks in the Early Palaeoproterozoic Dales Gorge Member of Western Australia," Sedimentary Geology, Vol. 170, No. 1-2, 2004, pp. 37-62. doi:10.1016/j.sedgeo.2004.06.007

[23] H. P. Eugster and I.-M. Chou, "The Depositional Environments of Precambrian Banded Iron-Formations," Economic Geology, Vol. 68, No. 7, 1973, pp. 1144-1168. doi:10.2113/gsecongeo.68.7.1144

[24] R. Buick and J. S. R. Dunlop, "Evaporitic Sediments of 
Early Archaean Age from the Warrawoona Group, North Pole, Western Australia," Sedimentology, Vol. 37, No. 2, 1990, pp. 247-277. doi:10.1111/j.1365-3091.1990.tb00958.x

[25] A. Gandin, et al., "Vanished Evaporates and Carbonate Formation in the Neoarchaean Kogelbeen and Gamohaan Formations of the Campbellrand Subgroup, South Africa," Journal of African Earth Sciences, Vol. 41, No. 1-2, 2005, pp. 1-23. doi:10.1016/i.jafrearsci.2005.01.003

[26] E. A. Gaucher, et al., "Palaeotemperature Trend for Precambrian Life Inferred from Resurrected Proteins," Nature, Vol. 451, No. 7179, 2008, pp. 704-707. doi:10.1038/nature06510

[27] F. Robert and M. Chaussidon, "A Paleotemperature Curve for the Precambrian Oceans Based on Silicon Isotopes in Cherts," Nature, Vol. 443, No. 7036, 2006, pp. 969-972. doi:10.1038/nature05239

[28] E. G. Nisbet and N. H. Sleep, "The Habitat and Nature of Early Life," Nature, Vol. 409, No. 6823, 2001, pp. 10831091. doi: $10.1038 / 35059210$

[29] D. Y. Sumner and J. P. Grotzinger, "Implications for Neoarchaean Ocean Chemistry from Primary Carbonate Mineralogy of the Campbellrand-Malmani Platform, South Africa," Sedimentology. Vol. 51, No. 6, 2004, pp. 12731299. doi:10.1111/j.1365-3091.2004.00670.x

[30] H. Dalstra, "Cover Photo," Geology, Vol. 31, No. 10. 2003, cover photo.

[31] Z. Lewy, "Early Precambrian Banded Iron Formations: Biochemical Precipitates from Highly Evaporated Hydrothermal Solutions of Polar Region Lakes," Carbonates and Evaporites, Vol. 24, No. 1, 2009, pp. 1-15.

[32] M. G. Miller and R. K. O'Nions, "Sources of Precambrian Chemical and Clastic Sediments," Nature, Vol. 314, No. 6009, 1985, pp. 325-330. doi:10.1038/314325a0

[33] A. F. Trendall, "Second Progress Report on the Brockman Iron Formation in the Wittenoom-Yampire Area," Geological Survey of Western Australia Annual Report 1965, 1966, pp. 75-87.

[34] M. Idnurm and J. W. Giddings, "Australian Precambrian Polar Wander: A Review," Precambrian Research, Vol. 40-41, 1988, pp. 61-88. doi:10.1016/0301-9268(88)90061-7

[35] M. W. McElhinny and M. O. McWilliams, "Precambrian Geodynamics - A Palaeomagnetic View," Tectonophysics, Vol. 40, No. 1-2, 1977, pp. 137-159. doi:10.1016/0040-1951(77)90032-4

[36] D. T. A. Symons, "Huronian Glaciation and Polar Wander from the Gowganda Formation, Ontario," Geology, Vol. 3, No. 6, 1975, pp. 303-306. doi:10.1130/0091-7613(1975)3<303:HGAPWF>2.0.CO;2

[37] V. A. Melezhnik, "Huronian Glaciation and Polar Wander from the Gowganda Formation, Ontario," Geology, Vol. 3, 2006, pp. 130-137.

[38] D. A. Evans, et al., "Low-Latitude Glaciation in the Palaeoproterozoic Era," Nature, Vol. 386, No. 6622, 1997, pp. 262-266. doi:10.1038/386262a0

[39] D. McB. Martin, "Depositional Setting and Implications of Paleoproterozoicglaciomarine Sedimentation in the
Hamersley Province, Western Australia," Geological Survey of America Bulletin, Vol. 111, No. 2, 1999, pp. 189203.

[40] T. D. Brock, "Environmentl Microbiology of Living Stromatolites," In: M. R. Walter, Ed., Stromatolites. Developments in Sedimentology, Vol. 20, 1976, pp. 141-148. doi: $10.1038 / 303163 \mathrm{a} 0$

[41] P. S. Braterman, et al., "Photo-Oxidation of Hydrated $\mathrm{Fe}^{2++}$-Significance for Banded Iron Formations," Nature, Vol. 303, No. 5913, 1983 pp. 163-164.

[42] W. W. Fischer and A. H. Knoll, "An Iron Shuttle for Deepwater Silica in Late Archean and Early Paleoproterozoic Iron Formation," GSA Bulletin, Vol. 121, No. 1-2, 2009, pp. 222-235.

[43] N. J. Beukes, "Facies Relations, Depositional Environments and Diagenesis in a Major Early Proterozoic Stromatolitic Carbonate Platform to Basinal Sequence, Campbellrand Subgroup, Transvaal Supergroup, Southern Africa," Sedimentary Geology, Vol. 54, 1987, pp. 1-46. doi:10.1016/0037-0738(87)90002-9

[44] W. Altermann and H.-G. Herbig, "Tidal Flat Peposits of the Lower Proterozoic Campbell Group along the Southwestern Margin of the Kaapvaal Craton, Northern Cape Province, South Africa," Journal of African Earth Sciences, Vol. 13, No. 3-4, 1992, pp. 415-435. doi:10.1016/0899-5362(91)90106-9

[45] W. Altermann, "The Evolution of Life and Its Impact on Sedimentation," Special Publications of the International Association of Sedimentologists, Vol. 33, 2002, pp.15-32.

[46] M. R. Walter, "Geyserites of Yellowstone National Park: An Example of Abiogenic Stromatolites," In: M. R. Walter, Ed., Stromatolites. Developments in Sedimentology, Vol. 20, Elsevier, Amsterdam, 1976, pp. 87-112.

[47] J. R. Eggleston and W. E. Dean, "Freshwater Stromatolitic Bioherms in Green Lake, New York," In: M. R. Walter, Ed., Stromatolites. Developments in Sedimentology, Vol. 20, Elsevier, Amsterdam, 1973, pp. 479-488.

[48] R. C. Surdam and J. L. Wray, "Lacustrine Stromatolites, Eocene Green River Formation, Wyoming," In: M. R. Walter, Ed., Stromatolites. Developments in Sedimentology, Vol. 20, Elsevier, Amsterdam, 1976, pp. 535-541.

[49] B. M. Simonson and A. D. T. Goode, "First Discovery of Ferruginous Chert Arenites in the Early Precambrian Hamersley Group of Western Australia," Geology, Vol. 17, No. 3, 1989, pp. 269-272. doi:10.1130/0091-7613(1989)017<0269:FDOFCA $>2.3 . C$ $\underline{\mathrm{O} ; 2}$

[50] N. J. Bukes and C. Klein, "Geochemistry and Sedimentology of a Facies Transition-From Microbanded to Granular Iron-Formation-In the Early Proterozoic Transvaal Supergroup, South Africa," Precambrian Research, Vol. 47, No. 1-2, 1990, pp. 99-139.

[51] I. W. Hälbich, et al., "Carbonate-Banded Iron Formation Transition in the Early Proterozoicum of South Africa," Journal of African Earth Sciences, Vol. 15, No. 2, 1992, pp. 217-236. doi:10.1016/0899-5362(92)90070-S

[52] R. Buick and J. S. R. Dunlop, "Evaporitic Sediments of Early Archaean Age from the Warrawoona Group, North 
Pole, Western Australia," Sedimentology, Vol. 37, No. 2, 1990, pp. 247-277.

doi:10.1111/j.1365-3091.1990.tb00958.x

[53] K. Sugitani, et al., "Stratigraphy and Sedimentary Petrology of an Archean Volcanic-Sedimentary Succession at Mt. Goldsworthy in the Pilbara Block, Western Australia: Implications of Evaporate (Nahcolite) and Barite Deposition," Precambrian Research, Vol. 120, No. 1-2, 2003, pp. 55-79. doi:10.1016/S0301-9268(02)00145-6

[54] A. Gadin, et al., "Vanished Evaporates and Carbonate Formation in the Neoarchaean Kogelbeen and Gamohaan formations of the Campbellrand Subgroup, South Africa," Journal of African Earth Sciences, Vol. 41, No. 1-2, 2005 , pp. 1-23. doi:10.1016/j.jafrearsci.2005.01.003

[55] N. T. Arndt, "Why Was Flood Volcanism on Submerged Continental Platforms So Common in the Precambrian?" Precambrian Research, Vol. 97, No. 3-4, 1999, p. 155. doi:10.1016/S0301-9268(99)00030-3

[56] M. E. Barley, et al., "Sedimentary Evidence for an Archaean Shallow-Water Volcanic-Sedimentary Facies, Eastern Pilbara Block, Western Australia," Earth and Pla- netary Science Letters, Vol. 43, No. 1, 1979, pp. 74-84. doi:10.1016/0012-821X(79)90156-0

[57] D. R. Lowe and L. P. Knauth, "Sedimentology of the Onverwacht Group (3.4 Billion Years), Rransvaal, South Africa, and Its Bearing on the Characteristics and Evolution of the Early Earth," Journal of Geology, Vol. 85, 1977, pp. 699-723. doi:10.1086/628358

[58] J. P. Harnmeijer, "Squeezing Blood from a Stone: Inference into the Life and Depositional Environments," Ph.D. Thesis, University of Washington, Washington, 2010.

[59] A. Bekker, J. F. Slack, N. Planavsky, B. Krapež, A. Hofmann, K. O. Konhauser and O. J. Rouxel, "Iron Formation: The Sedimentary Product of a Complex Interplay Among Mantle, Tectonic, Oceanic and Biospheric Processes," Economic Geology, Vol. 105, No. 3, 2010, pp. 467-508. doi:10.2113/gsecongeo.105.3.467

[60] N. J. Planavsky, P. McGoldrick, C. T. Scott, C Li, C. T. Reinhard, A. E. Kelly, X. Chu, A. Bekker, G. D. Love and T. W. Lyons, "Widespread Iron-Rich Conditions in the Mid-Proterozoic Ocean," Nature, Vol. 477, No. 7356, 2011, pp. 448-451. doi:10.1038/nature10327 